\title{
Hypertension is the underlying cause of death assessed at the autopsy of individuals*
}

\author{
A hipertensão arterial é causa subjacente de morte avaliada na autópsia de indivíduos \\ La hipertensión arterial es causa subyacente de muerte evaluada en la autopsia de individuos
}

How to cite this article:

Coelho JC, Ferretti-Rebustini REL, Suemoto CK, Leite REP, Jacob-Filho W, Pierin AMG. Hypertension is the underlying cause of death assessed at the autopsy of individuals. Rev Esc Enferm USP. 2019;53:e03457. DOI: http://dx.doi.org/10.1590/S1980-220X2018006103457

Juliana Chaves Coelho ${ }^{1}$

Renata Eloah de Lucena FerrettiRebustini ${ }^{1}$

Claudia Kimie Suemoto ${ }^{2}$

Renata Elaine Paraizo Leite ${ }^{2}$

Wilson Jacob-Filho ${ }^{2}$

Angela Maria Geraldo Pierin ${ }^{1}$

* Extracted from the dissertation: "Hipertensão arterial: estudo post mortem na região metropolitana de São Paulo”, Escola de Enfermagem, Universidade de São Paulo, 2016.

${ }^{1}$ Universidade de São Paulo, Escola de Enfermagem, São Paulo, SP, Brazil.

2 Universidade de São Paulo, Faculdade de Medicina, São Paulo, SP, Brazil.

\begin{abstract}
Objective: To analyze hypertension and its relationship with the causes of death identified by the autopsy. Method: Cross-sectional study analyzed 356 participants belonging to the Brazilian Aging Brain Study Group, over 50 years of age, autopsied at the Sao Paulo Autopsy Service between 2004 to 2014. A clinical interview was conducted with the informant of the deceased. Hypertension was defined by reporting the disease and/or use of antihypertensive medication, by the informant of the deceased. Descriptive analyzes and bivariate and multivariable associations were performed. Results: The prevalence of hypertension was $66.2 \%$ and it was the second leading cause of death $(25.6 \%)$ identified by autopsy, preceded by atherosclerosis $(37.8 \%)$. The variables associated with hypertension were: female gender $(\mathrm{OR}=2.30$ (1.34-3.90)); living with partner $[\mathrm{OR}=0.55(0.32-0.92)]$; Body Mass Index [OR=1.14 (1.08-1.22)] and history of diabetes $[\mathrm{OR}=2.39(1.34-4.27)]$. Conclusion: The prevalence of hypertension was high, and it was the second most common underlying cause of death. The gold standard for the definition of cause of death, the autopsy, shows important results, which confirmed the relevance of hypertension as a public health problem.
\end{abstract}

\section{DESCRIPTORS}

Hypertension; Cause of Death; Mortality; Autopsy. 


\section{INTRODUCTION}

Hypertension is one of the main risk factors for cardiovascular diseases, the main cause of death ${ }^{(1)}$. The prevalence of hypertension in Brazil, in a meta-analysis study covering the 1980 to 2000 period, was estimated to be $31 \%$ in the general population ${ }^{(2)}$. According to the Brazilian Hypertension Guidelines, the disease can be classified in different stages (I, II or III), depending on blood pressure values and patients should be stratified according to the presence of additional risk factors or injury in target organs, in order to optimize the therapeutic decision ${ }^{(1)}$. The high prevalence of the disease, in addition to the unsatisfactory control of hypertension, since only $30 \%$ of hypertensive patients have controlled blood pressure ${ }^{(3)}$, and problems related to diagnosis and treatment, are also potential agents for lesions in target organs, raising the mortality rate ${ }^{(4)}$.

In the United States, hypertension-related deaths increased $61.8 \%$ between 2000 and $2013^{(5)}$ and, in an autopsy study, hypertensive diseases were the main cause of cardiovascular death ${ }^{(6)}$. However, in Brazil, there are few studies evaluating the association between hypertension and causes of death using autopsy, which is considered as gold standard to define the cause of death.

Therefore, this study aimed to analyze hypertension and its relation to the causes of deaths identified by autopsy in newly deceased individuals.

\section{METHOD}

\section{Study DESIGN}

This is a cross-sectional study.

\section{Population}

The data were collect from the Brazilian Aging Brain Study Group, Medical School, Universidade de São Paulo. The Brain Bank collects clinical information with the informants of the deceased through a semi-structured interview composed of validated instruments for post-mortem research ${ }^{(7)}$. Interviews are conducted by trained nurses. The autopsy data comes from Sao Paulo Autopsy Service, which verifies the cause of death by natural cause not established through the autopsy. The population was composed of people who died between 2004 and 2014.

\section{SeleCtion CRITERIA}

Inclusion criteria in the Brain Bank are: 50 years of age and higher; death by natural causes and; have an informant with minimum weekly living with the deceased. Exclusion criteria are: death due to brain pathologies that make impossible the macroscopic evaluation of the brain, such as hemorrhagic encephalic stroke; disease responsible for causing hypoxia or cerebral hypo-flow; or history of prolonged cardiorespiratory arrest in the three months prior to death.

\section{SAMPLE DEFINITION}

The sample was calculated based on the prevalence of $65 \%$ of hypertension in the Brazilian elderly population ${ }^{(8)}$, since the deceased persons included in the Brain Bank were older than 50 years. Thus, a sample of 341 individuals was calculated, with 356 cases being collected in order to cover possible data losses. In order to produce a representative sample of the total cases and to minimize the interference of the researcher, we opted for simple randomization. The draw was made by computer from the case number.

\section{Data collection}

Data were collected retrospectively. The dependent study variable was hypertension. The criterion used to define hypertension was the report of the disease, by the informant of the deceased, as a personal antecedent in life and/or report of use of antihypertensive drugs. The independent variables were: age, sex, ethnicity (white and nonwhite); marital status (with partner or without partner); profession (retired, with employment relationship, housewife, pensioner, self-employed or without occupation); schooling (illiterate, incomplete elementary, complete elementary, high school or higher education); socioeconomic classification (classes A, B, C, D and E, defined by the Critério de Classificação Econômica Brasil (CCEB - Brazilian Economic Classification Criteria)). This stratification criterion aims to generate a standardized scoring system that predicts consumption capacity of individuals and families, capable of discriminating large groups according to their capacity to consume products and services accessible to a significant part of the population ${ }^{(9)}$. The comorbidities reported by the informants of the deceased were diabetes, coronary artery disease, heart failure, arrhythmia, dyslipidemia, use of pacemaker, chronic renal insufficiency, stroke, chronic pulmonary diseases, depression, rheumatic diseases, cancer, peripheral vascular disease, neurodegenerative diseases and infectious diseases; and family history of hypertension, acute myocardial infarction, stroke, cancer, diabetes and neurodegenerative diseases. The presence of depression was assessed by the Structural Clinical Interview for DSM Disorders - SCID ${ }^{(10)}$. The life habits evaluated were: smoking and alcoholism (yes or no) and physical activity (sedentary or active). Body Mass Index (BMI) was obtained from the weight and height, measured with the deceased in the supine position without clothes, by a technician of the service. The drugs were classified according to the drug class (hypoglycemic agents, anticoagulants/antiplatelet, cardiotonics, psychotropic agents, bronchodilators, lipid-lowering agents, analgesics, gastric shields and antihypertensive drugs). The causes of death were identified at the autopsy performed by a pathologist and classified through the International Classification of Diseases and Related Health Problems (ICD-10). Causes of death were detailed in immediate cause, main disease related to death and basic cause. The autopsy begins by 
external inspection or ectoscopy of the body. The internal examination, the next stage of the autopsy, is divided into an internal examination of the head (cranial cavity) and the trunk (thoracic and abdominal cavities) and it is begun by incision. The pathologist examines the body cavities and describes the possibility of air (pneumothorax, for example). He measures the volume of fluids and blood, examining the integrity and limits of the anatomy, evaluating the external appearance of the organs and their location; and detects adhesions and obliteration of the cavities, and lesions and hemorrhages, according to the general principles of pathological anatomy. Samples of suspicious areas of organs such as kidney, spleen, lung, liver, heart and brain are collected for anatomopathological analysis. A brief family report in terms of how death occurred, and preexisting diseases are also collected to confront macro and microscopic findings ${ }^{(11)}$.

\section{DATA ANALYSIS AND TREATMENT}

The analyzes were performed by the SPSS 22.0 statistical program. The level of significance was set at 0.05 . We used means and standard deviations of the quantitative variables, as well as absolute (n) and relative (\%) frequencies for descriptive analyzes. The association between categorical variables and hypertension was analyzed by the chi-square test or Fisher's test, when appropriate. The differences between the means of the quantitative variables were analyzed by the $\mathrm{t}-\mathrm{Student}$ test. The variables associated to hypertension identified as $\mathrm{p}<0.20$ were included in the multivariate analysis, performed by logistic regression.

\section{ETHICAL ASPECTS}

The project was approved by the Research Ethics Committee of the Universidade de São Paulo School of Nursing, in 2016, opinion number 1.464.686. All cases belonging to the Brain Bank had a signed consent form. For the accomplishment of this study, the Guidelines and Norms Regulating Investigations involving Human Beings were followed, according to the Resolution n ${ }^{\circ} .466 / 2012$ of the National Health Council ${ }^{(12)}$.

\section{RESULTS}

Data from 356 deceased persons were evaluated. The mean age was 70.83 (11.54) years; the majority were male (56.2\%), retired (53.7\%), smoker (55.1\%), sedentary (57.5\%), white ethnicity (68\%), low schooling (19\% were Illiterate and $63 \%$ had incomplete elementary school), low socioeconomic classification ( $71.5 \%$ in classes $\mathrm{C}, \mathrm{D}$ and $\mathrm{E}$ ); Considerable number had a partner (48\%); and less than a third (28.7\%) were alcoholic.

The prevalence of hypertension, reported by the informants, was $66.3 \%$. The number of people with hypertension was higher in relation to non-hypertensive individuals $(\mathrm{p}<0.05)$, as most of them were female, housewives, had a greater number of children, and had a higher body mass index (Table 1).
Table 1 - Biosocial variables and habits and lifestyles in the deceased, according to the hypertensive and non-hypertensive groups, corresponding to information reported by the relative São Paulo, 2004-2014.

\begin{tabular}{|c|c|c|c|}
\hline \multirow[t]{2}{*}{ Variable } & Hypertensive & $\begin{array}{c}\text { Non- } \\
\text { hypertensive }\end{array}$ & \multirow[t]{2}{*}{ p Value } \\
\hline & N (\%) & N (\%) & \\
\hline \multicolumn{4}{|l|}{ Sex } \\
\hline Male & $121(51.3)$ & $79(65.8)$ & \multirow{2}{*}{$0.009 *$} \\
\hline Female & $115(48.7)$ & $41(34.2)$ & \\
\hline \multicolumn{4}{|l|}{ Race } \\
\hline White & $160(67.8)$ & $82(68.3)$ & \multirow{2}{*}{$0.91^{+}$} \\
\hline Nonwhite & $76(32.2)$ & $38(31.7)$ & \\
\hline \multicolumn{4}{|l|}{ Marital status } \\
\hline With partner & $121(51.3)$ & $50(41.7)$ & \multirow{2}{*}{$0.08^{*}$} \\
\hline Without partner & $115(48.7)$ & $70(58.3)$ & \\
\hline \multicolumn{4}{|l|}{ Profession $(\mathrm{N}=354)$} \\
\hline Retired & $121(51.2)$ & $69(58.5)$ & \multirow{6}{*}{$\mathbf{0 . 0 0 1}^{+}$} \\
\hline Employed & $34(14.4)$ & $25(21.2)$ & \\
\hline Housewife & $46(19.5)$ & $8(6.8)$ & \\
\hline Pensioner & $28(11.9)$ & $8(6.8)$ & \\
\hline Self-employed & $7(3.0)$ & $6(5.0)$ & \\
\hline No occupation & $0(0.0)$ & $2(1.7)$ & \\
\hline \multicolumn{4}{|l|}{ Education (N= 348) } \\
\hline Illiterate & $49(21.3)$ & $17(14.4)$ & \multirow{5}{*}{$0.226^{\dagger}$} \\
\hline Incomplete elementary school & $135(58.7)$ & $84(71.2)$ & \\
\hline Complete elementary school & $21(9.1)$ & $6(5.1)$ & \\
\hline High school & $19(8.3)$ & $8(6.8)$ & \\
\hline Higher education & $6(2.6)$ & $3(2.5)$ & \\
\hline \multicolumn{4}{|c|}{ Socioeconomic Classification $(\mathrm{N}=353)$} \\
\hline A to $B$ & $72(30.9)$ & $29(24.1)$ & \multirow{4}{*}{$0.114^{+}$} \\
\hline C & $103(44.2)$ & $68(56.7)$ & \\
\hline $\mathrm{D}$ & $57(24.5)$ & $21(17.5)$ & \\
\hline E & $1(0.4)$ & $2(1.7)$ & \\
\hline Smoking & $131(55.0)$ & $65(54.2)$ & $0.81 *$ \\
\hline Alcoholism & $60(25.4)$ & $42(35.0)$ & $0.059 *$ \\
\hline Sedentary life style & $125(57.6)$ & $63(57.3)$ & $0.95^{*}$ \\
\hline Age, years, mean (SD) & $70.67(10.8)$ & $71.15(12.8)$ & $0.713^{\ddagger}$ \\
\hline BMI, Kg/m², mean (SD) & $24.10(4.33)$ & $21.44(4.221)$ & $<\mathbf{0 . 0 0 0}^{\ddagger}$ \\
\hline
\end{tabular}

Hypertension was the most reported disease (62.9\%) in the personal history. The other comorbidities reported were diabetes mellitus (28.1\%), as the second most informed cause and, less frequently, coronary artery disease (18.8\%), heart failure (14.0\%) and stroke (12.9\%). Depression was identified in $15.4 \%$ of the deceased. In the family history, acute myocardial infarction was the most cited (28.2\%), followed by cancer (17.3\%) and hypertension (17\%). The deceased hypertensives compared to non-hypertensive individuals presented more $(p<0.05)$ personal antecedents for diabetes, coronary artery disease, heart failure, stroke, arrhythmia and family history for hypertension, but had less cancer and personal and family antecedent for neurodegenerative diseases (Table 2). 
Table 2 - Personal and family history of referred diseases in deceased persons, according to the hypertensive and nonhypertensive groups, corresponding to information reported by the relative - São Paulo, 2004-2014.

\begin{tabular}{|c|c|c|c|}
\hline \multirow[t]{2}{*}{ Variable } & Hypertensive & $\begin{array}{c}\text { Non- } \\
\text { hypertensive }\end{array}$ & \multirow[t]{2}{*}{ p Value } \\
\hline & $N(\%)$ & N (\%) & \\
\hline \multicolumn{4}{|l|}{ Personal background } \\
\hline Diabetes Mellitus & $81(34.3)$ & $19(15.8)$ & $<0.0001^{*}$ \\
\hline Coronary artery disease & $61(25.4)$ & $7(5.8)$ & $<0.0001^{*}$ \\
\hline Heart Failure & $44(18.6)$ & $6(5.0)$ & $<0.0001^{*}$ \\
\hline Stroke & $40(16.9)$ & $6(5.0)$ & $0.001 *$ \\
\hline Chronic renal insufficiency & $29(12.3)$ & $12(10.0)$ & $0.523^{*}$ \\
\hline Dyslipidemia & $26(11.0)$ & $6(5.0)$ & $0.061^{*}$ \\
\hline Cancer & $12(5.1)$ & $16(13.3)$ & $0.006^{*}$ \\
\hline Arrhythmia & $24(9.7)$ & $2(1.7)$ & $0.005^{*}$ \\
\hline Depression & $12(5.1)$ & $7(5.8)$ & $0.766^{*}$ \\
\hline Vascular disease & $15(6.4)$ & $2(1.7)$ & $0.051^{*}$ \\
\hline Neurodegenerative diseases & $6(2.5)$ & $9(7.5)$ & 0.028* \\
\hline Major depressive episode & $41(17.4)$ & $14(11.7)$ & $0.159^{*}$ \\
\hline \multicolumn{4}{|l|}{ Family history } \\
\hline Acute myocardial infarction & $56(28.9)$ & $27(27.0)$ & $0.646^{*}$ \\
\hline Cancer & $32(16.5)$ & $19(19.0)$ & $0.453^{*}$ \\
\hline Hypertension & $41(21.1)$ & $9(9.0)$ & $0.031^{*}$ \\
\hline Stroke & $31(16.0)$ & $11(11.0)$ & $0.413^{*}$ \\
\hline Diabetes Mellitus & $28(14.4)$ & $13(13.0)$ & $0.643^{*}$ \\
\hline Neurodegenerative diseases & $5(2.6)$ & $11(11.0)$ & 0.004* \\
\hline
\end{tabular}

Most informants (77.5\%) reported that the deceased person used at least one drug, with antihypertensive drugs being the most reported (52\%). The data in Table 3 show the other drugs mentioned: hypoglycemic agents (17.2\%), anticoagulants/antiplatelet agents (16.9\%) and cardiotonics (9.8\%). The hypertensive individuals were different from non-hypertensive individuals due to the higher use of hypoglycemic agents, anticoagulants/antiplatelet agents and a lesser use of analgesics $(p<0.05)$.

Among those who had hypertension, $77 \%$ used some type of antihypertensive drug, but $43.1 \%$ of the informants did not know the name of the medications. Among those who reported the name of the drug, about half (50.2\%) reported Angiotensin-Converting Enzyme Inhibitors (ACE), followed by diuretics (35.3\%), in lower proportions, beta-blockers (11.3\%), calcium channel blockers (7.1\%) and central-acting agents (1.7\%).

Table 3 - Use of drugs of the deceased, according to the hypertensive and non-hypertensive groups, corresponding to information reported by the relative - São Paulo, 2004-2014.

\begin{tabular}{|c|c|c|c|}
\hline \multirow{2}{*}{ Variable } & Hypertense & Non-hypertense & \multirow{2}{*}{ p Value } \\
\hline & $N(\%)$ & N (\%) & \\
\hline Hypoglycemic agents & 48 (20.9) & $10(9.3)$ & $0.027^{*}$ \\
\hline $\begin{array}{l}\text { Anticoagulants/ } \\
\text { antiplatelet /Antiplatelet }\end{array}$ & $50(21.7)$ & $7(6.5)$ & $0.002 *$ \\
\hline Cardiotonics & $26(11.3)$ & $7(6.5)$ & $0.30^{*}$ \\
\hline Psychotropic & $15(6.5)$ & $8(7.4)$ & $0.684^{*}$ \\
\hline Bronchodilators & $11(4.8)$ & $5(4.6)$ & $0.729 *$ \\
\hline Hipolipemiants & $13(5.7)$ & $1(0.9)$ & $0.09^{* *}$ \\
\hline Analgesics & $2(0.9)$ & $10(9.3)$ & $<0.0001^{+}$ \\
\hline Gastric shield & $6(2.6)$ & $4(3.7)$ & $0.557^{+}$ \\
\hline
\end{tabular}

Data in Table 4 show the causes of death identified by autopsy, present in the death certificate, described in immediate cause, basic cause and main disease related to death. The immediate causes are illnesses or complications that directly caused death, while the underlying causes are diseases or injuries that started the chain of morbid events and led directly and inevitably to death.

The analysis of the causes of death identified at the autopsy showed that the most frequent cause of death was pulmonary edema (31.1\%) and, secondly, ischemic heart disease (25.0\%). Atherosclerosis was the leading cause of death (37.8\%), followed by hypertension (25.6\%). In relation to the main disease related to death, ischemic heart diseases (19.5\%) and atherosclerosis (18.8\%) were the most frequent, and, at a lower frequency, hypertensive diseases $(9.57 \%)$ and other forms of Heart disease (9.24\%).

In the assessment of the immediate cause of death, hypertensive patients died more of ischemic heart disease $(28.3 \%$ vs 18.3\%); however, hypertensive patients died with less frequency of infectious diseases (10.1\% vs $24.1 \%)$ and chronic diseases of the lower airways (2.1\% vs $7.5 \%)$. Regarding the underlying cause of death, patients died more of hypertension (30.6\% vs 14.6\%) than of neoplasms (5.6\% vs 20.8\%). As to the main disease related to death, hypertensive patients compared to non-hypertensive patients presented more ischemic heart diseases (23.4\% vs $11.8 \%)$, atherosclerosis $(22.9 \%$ vs. $10.8 \%$ ) and hypertension (8.0\% vs $1.0 \%)$, but less infectious diseases (6\% vs 13.7\%) and neoplasms (3.0\% vs 13.7\%).

Table 4 - Causes of death obtained by autopsy in deceased persons, according to the hypertensive and non-hypertensive groups, corresponding to information reported by the relative - São Paulo, 2004-2014.

\begin{tabular}{lcccc}
\hline \multirow{2}{*}{ Variable } & Hypertense & Non-hypertense & Total & p Value \\
\cline { 2 - 4 } & $\mathbf{N}(\%)$ & $\mathbf{N}(\%)$ & $\mathbf{N}(\%)$ & \\
\hline Immediate cause $(\mathrm{N}=356)$ & & & & $0.19^{*}$ \\
Pulmonary edema & $79(33.4)$ & $32(26.6)$ & $111(31.1)$ & $\mathbf{0 . 0 3}^{*}$ \\
Ischemic heart disease & $67(28.3)$ & $22(18.3)$ & $89(25.0)$ & \\
\hline
\end{tabular}




\begin{tabular}{|c|c|c|c|c|}
\hline \multirow{2}{*}{ Variable } & Hypertense & Non-hypertense & Total & \multirow{2}{*}{ p Value } \\
\hline & $N(\%)$ & $N(\%)$ & $N(\%)$ & \\
\hline Infectious diseases & $24(10.1)$ & $29(24.1)$ & $53(14.8)$ & $<0.0001 *$ \\
\hline $\begin{array}{l}\text { Pulmonary } \\
\text { thromboembolism }\end{array}$ & $15(6.3)$ & $10(8.3)$ & $25(7.0)$ & $0.49^{*}$ \\
\hline Other forms of heart disease & $16(6.7)$ & $3(2.5)$ & $19(5.3)$ & $0.08^{*}$ \\
\hline $\begin{array}{l}\text { Chronic diseases of the } \\
\text { lower airways }\end{array}$ & $5(2.1)$ & $9(7.5)$ & $14(3.9)$ & $0.02^{+}$ \\
\hline Hypertensive diseases & $7(2.9)$ & $1(0.8)$ & $8(2.2)$ & $0.27^{+}$ \\
\hline $\begin{array}{l}\text { Diseases of the digestive } \\
\text { system }\end{array}$ & $3(1.2)$ & $4(3.3)$ & $7(1.9)$ & $0.23^{+}$ \\
\hline Cerebrovascular diseases & $5(2.1)$ & $1(0.8)$ & $6(1.6)$ & $0.66^{+}$ \\
\hline Shock & $5(2.1)$ & $0(0.0)$ & $5(1.4)$ & $0.17^{+}$ \\
\hline \multicolumn{5}{|l|}{ Basic Cause $(\mathrm{N}=156)$} \\
\hline Atherosclerosis & $45(41.7)$ & $14(29.2)$ & $59(37.8)$ & $0.13^{*}$ \\
\hline Hypertension & $33(30.6)$ & $7(14.6)$ & $40(25.6)$ & $0.03^{*}$ \\
\hline Cancer & $6(5.6)$ & $10(20.8)$ & $16(10.2)$ & $0.008^{*}$ \\
\hline Other forms of heart disease & $7(6.5)$ & $4(8.3)$ & $11(7.0)$ & $0.73^{+}$ \\
\hline Ischemic heart disease & $7(6.5)$ & $1(2.1)$ & $8(5.2)$ & $0.43^{+}$ \\
\hline Infectious diseases & $5(4.6)$ & $2(4.2)$ & $7(4.4)$ & $1.00^{+}$ \\
\hline $\begin{array}{l}\text { Diseases of the digestive } \\
\text { system }\end{array}$ & $2(1.9)$ & $4(8.3)$ & $6(3.8)$ & $0.07^{+}$ \\
\hline \multicolumn{5}{|c|}{ Primary illness related to death $(\mathrm{N}=303)$} \\
\hline Ischemic heart disease & $47(23.4)$ & $12(11.8)$ & $59(19.5)$ & $0.01 *$ \\
\hline Atherosclerosis & $46(22.9)$ & $11(10.8)$ & $57(18.8)$ & $0.01 *$ \\
\hline Hypertensive diseases & $22(10.9)$ & $7(6.9)$ & $29(9.5)$ & $0.25^{*}$ \\
\hline Other forms of heart disease & $18(9.0)$ & $10(9.8)$ & $28(9.2)$ & $0.81^{*}$ \\
\hline Infectious diseases & $12(6.0)$ & $14(13.7)$ & $26(8.6)$ & $0.02^{*}$ \\
\hline Cancer & $6(3.0)$ & $14(13.7)$ & $20(6.6)$ & $<0.0001^{*}$ \\
\hline Hypertension & $16(8.0)$ & $1(1.0)$ & $17(5.7)$ & $0.013^{*}$ \\
\hline Aortic aneurysm & $8(4.0)$ & $5(4.9)$ & $13(4.2)$ & $0.76^{+}$ \\
\hline $\begin{array}{l}\text { Pulmonary } \\
\text { thromboembolism }\end{array}$ & $6(3.0)$ & $5(4.9)$ & $11(3.6)$ & $0.51^{+}$ \\
\hline $\begin{array}{l}\text { Chronic diseases of the } \\
\text { lower airways }\end{array}$ & $4(2.0)$ & $5(4.9)$ & $9(2.9)$ & $0.17^{+}$ \\
\hline
\end{tabular}

${ }^{*} \chi^{2}$ test; + Fisher exact test.

In the multivariate analysis, the variables that were positively associated with hypertension were: personal history of diabetes [OR = 2.39 (CI95\%: 1.34-4.27)]; female [2.30 (CI95\%:1.343.90)] and Body Mass Index [1.14 (CI95\%: 1.08-1.22)].Living with a partner conferred greater chances of protection for hypertension [0.55 (CI95\%: 0.32-0.92)] (Table 5).

Table 5 - Logistic regression model: variables associated with arterial hypertension - São Paulo, 2004-2014.

\begin{tabular}{lcc}
\hline Variable & Unadjusted OR (IC95\%) & Adjusted OR (CI 95\%) \\
\hline Sex & \multicolumn{2}{c}{1 (reference) } \\
Male & $1.83(1.16-2.88)$ & $2.30(1.34-3.90)$ \\
Female & \multicolumn{2}{c}{1 (reference) } \\
\hline Marital status & $0.55(0.32-0.92)$ \\
Without partner & $0.67(0.43-1.05)$ & $1.14(1.08-1.22)$ \\
With partner & $1.15(1.09-1.22)$ & \\
\hline BMI & \multicolumn{1}{c}{1 (reference) } \\
\hline $\begin{array}{l}\text { Personal history of diabetes mellitus } \\
\text { No }\end{array}$ & $2.77(1.59-4.85)$ & $2.39(1.34-4.27)$ \\
Yes &
\end{tabular}

\section{DISCUSSION}

The main findings of the present study showed that hypertension was an important underlying cause of death, in addition to having a high prevalence. This prevalence is compatible with other findings. In Brazil, epidemiological studies and systematic review indicate that the prevalence of hypertension in the general population is around $30 \%{ }^{(2,13)}$. Data from England, United States and Canada indicate percentages of $30 \%, 29.1 \%$ and $19.5 \%$ in the general population, respectively; and higher rates in the elderly, of $63.7 \%, 53.2 \%$ and $63.6 \%$, respectively ${ }^{(14)}$. Research performed with the same population had already shown a high and similar prevalence $(65.1 \%)^{(9)}$, as well as in other Brazilian studies with an elderly population $^{(3,15)}$. Age was not associated with hypertension and remained around the seventh decade in the deceased studied, being able to explain the high prevalence of hypertension.

Regarding gender, which was one of the variables that remained in the multivariate analysis, associated with 
hypertension, women had a chance of hypertension almost twice as high as men. National survey found a difference between the sexes only for the age group over 70 years $(82.4 \% \text { in women vs } 57.1 \% \text { in men, } \mathrm{p}<0.05)^{(16)}$. Similarly, the American Heart Association identified higher prevalence among women aged 65 years or older compared to men of the same age ${ }^{(1)}$. In females, possibly due to the postmenopausal period, in addition to the known mechanisms of pressure control, there is the additional effect of hormonal decline, which may justify these findings ${ }^{(17)}$. On the other hand, a study showed that hypertensive women were more controlled than men, despite the existence of biopsychosocial variables that may influence negatively adherence to treatment ${ }^{(18)}$.

Another important finding was that living with a partner conferred lower chances for the existence of arterial hypertension when compared to those who did not have a partner. In that sense, a study showed that widows ${ }^{(19)}$ had a $20 \%$ higher risk of having hypertension than those who were married, suggesting that living without a partner could increase the risk for the disease. The "housewife" occupation was not associated with hypertension in the multivariate analysis, but it showed a relation with hypertension in the bivariate analysis. This can be explained by the fact that most of the hypertensive population has low schooling and low income, characterizing the profile of people without formal work. Although in the present study hypertension was not associated with schooling or socioeconomic status, another study found association between low schooling and income with the presence of hypertension ${ }^{(20)}$.

Body mass index was associated with hypertension in the multivariate analysis model, and the literature has reinforced the association between obesity and hypertension ${ }^{(21-22)}$. Data from Brazil, from 1975 to 2003, showed an expressive increase in the prevalence of overweight and obesity, representing one of the most challenging problems. Excessive weight and obesity are associated with morbidity, mortality, and significant costs in the health area ${ }^{(23)}$. Therefore, weight loss has been associated with a decrease in terms of cardiovascular complications and gain in life years ${ }^{(24)}$. Physical activity also plays an important role in the context of cardiovascular diseases. The performance of intense or moderate physical activity for 12 months represented a sustained improvement in abdominal obesity and blood pressure ${ }^{(25)}$. In the present study, hypertensive and non-hypertensive individuals were similar in relation to physical activity, but the level of sedentary lifestyle was high (57.5\%). Therefore, changes in habits and lifestyles can positively influence people's health and modify the mortality profile.

Variables of the personal history of diseases, related to cardiovascular risk factors, presented relevant prevalence. Only the report of diabetes mellitus was associated with hypertension in the multivariate model, increasing the chance of hypertension more than twice. In Brazil, the prevalence of diabetes in a multicenter study was $19.7 \%$; and $50.4 \%$ of this was not previously diagnosed and $79.1 \%$ presented intermediate hyperglycemia, showing the serious problem of the disease in the country ${ }^{(26)}$. Regarding the other comorbidities that were identified, the findings were similar to those of the study that showed that hypertensive patients had a higher prevalence of dyslipidemia, chronic kidney disease, obesity, diabetes and cardiovascular diseases, including stroke, acute myocardial infarction and angina ${ }^{(27)}$. The presence of multimorbidities in hypertensive individuals may contribute to potential complications for increased mortality. A meta-analysis study found that the reduction of $10 \mathrm{mmHg}$ in systolic pressure decreased $(\mathrm{p}<0.05)$ the risk of coronary heart disease, stroke and heart failure, as well as a $13 \%$ reduction in all-cause mortality ${ }^{(28)}$. This scenario plays an important role in the definition of therapeutic strategies, since hypertensive patients may present complications, which potentially increase mortality.

Depression has not been associated with hypertension, although, it is an important finding, since data from the Longitudinal Adult Health Study (ELSA) have indicated that psychopathological symptoms were directly associated with atherosclerosis and this association appeared to be stronger in people with more than 50 years of age ${ }^{(29)}$, age profile similar to that of the present study. Such associations are important to understand the relationship between cardiovascular diseases and psychopathological symptoms.

Regarding the causes of death, hypertension represented the second most frequent basic cause. It is also worth mentioning that other cardiac causes, such as ischemic and hypertensive diseases, added to hypertension, accounted for $41 \%$ of the basic causes of death in the sample studied. The causes of death due to hypertensive diseases have tended to increase in the last decades in $\mathrm{Brazil}^{(4)}$ and in the United States, where they increased by $23.1 \%$ in the period from 2000 to $2013^{(5)}$. The mortality trends of cardiovascular diseases in the regions of the Americas, since the 2000s, have declined by $29.5 \%$ in North America, lower falls (14.1\%) in Latin America and a decrease of only $10.9 \%$ in the Caribbean region ${ }^{(30)}$.

The present study presented some limitations. It is a transversal one, which does not allow to establish relations of cause and effect. Another limitation was the presence of death certificates with incomplete completion. In view of this, a detailed analysis of all the causes of death was chosen, aiming to better portray the mortality profile.

The advantages of the present study were the use of autopsy, considered gold standard in the definition of the cause of death and the inclusion of informants of the deceased persons who had minimally weekly contact with the deceased to reduce the information bias; in addition, the clinical interview was validated for the post-mortem collection ${ }^{(8)}$.

\section{CONCLUSION}

The prevalence of arterial hypertension identified in the present study was high, and data on death indicated that hypertension represented a major cause of death and was associated with demographic and personal antecedents. These results corroborate the high prevalence of the disease in the national scenario, showing its influence on mortality. In addition, the present study brought advances in the studies on arterial hypertension, when working with the gold standard to define the cause of death, the autopsy. 


\section{RESUMO}

Objetivo: Analisar a hipertensão e sua relação com as causas de morte identificadas pela autópsia. Método: Estudo transversal, que analisou 356 participantes do Biobanco para Estudos no Envelhecimento, com idade maior do que 50 anos, autopsiados no Serviço de Verificação de Óbitos entre os anos de 2004 a 2014. Uma entrevista clínica foi realizada com o informante do falecido. A hipertensão foi definida pelo relato da doença e/ou o uso de medicação anti-hipertensiva pelo informante do falecido. Foram realizadas análises descritivas e associações bivariadas e multivariáveis. Resultados: A prevalência de hipertensão arterial foi de $66,2 \%$ e foi a segunda causa básica de óbito $(25,6 \%)$ identificada na autópsia, precedida de aterosclerose $(37,8 \%)$. As variáveis associadas à hipertensão foram: gênero feminino $(\mathrm{OR}=2,30(1,34-3,90)$; ter um parceiro $[\mathrm{OR}=0,55(0,32-0,92)]$; índice de massa corporal $[\mathrm{OR}=1,14(1,08-1,22)]$ e história de diabetes $[\mathrm{OR}=2,39(1,34-4,27)]$. Conclusão: A prevalência de hipertensão foi elevada e representou a segunda causa básica de óbito mais frequente. $\mathrm{O}$ uso da autópsia como padrão-ouro para definir a causa da morte confirmou a relevância da hipertensão como um problema de saúde pública.

\section{DESCRITORES}

Hipertensão; Causa de Morte; Mortalidade; Autópsia.

\section{RESUMEN}

Objetivo: Analizar la hipertensión y su relación con las causas de muerte identificadas por la autopsia. Método: Estudio transversal, que analizó a 356 participantes del Biobanco para Estudios en el Envejecimiento, con edad mayor a 50 años, autopsiados en el Servicio de Verificación de Defunciones entre los años 2004 y 2014. Una entrevista clínica fue realizada con el informante del fallecido. La hipertensión fue definida por el relato de la enfermedad y/o uso de medicación antihipertensiva por el informante del fallecido. Se llevaron a cabo análisis descriptivos y asociaciones bivariadas y multivariables. Resultados: La prevalencia de hipertensión arterial fue del $66,2 \%$ y fue la segunda causa básica de defunción $(25,6 \%)$ identificada en la autopsia, precedida de aterosclerosis $(37,8 \%)$. Las variables asociadas con la hipertensión fueron: género femenino $(\mathrm{OR}=2,30(1,34-3,90)$; tener a una pareja [OR = 0,55 (0,32-0,92)]; índice de masa corporal $[\mathrm{OR}=1,14(1,08-1,22)]$ e historia de diabetes $[\mathrm{OR}=2,39(1,34-4,27)]$. Conclusión: La prevalencia de hipertensión fue elevada y representó la segunda causa básica de defunción más frecuente. El uso de la autopsia como regla de oro para definir la causa de la muerte confirmó la relevancia de la hipertensión como un problema de salud pública.

\section{DESCRIPTORES}

Hipertención; Causas de Muerte; Mortalidad; Autopsia.

\section{REFERENCES}

1. Mozaffarian D, Benjamin EJ, Go AS, Arnett DK, Blaha MJ, Cushman M, et al. Heart disease and stroke statistics-2015: update a report from the American Heart Association. Circulation. 2015;131(4):e29-322. DOI: 10.1161/CIR.0000000000000152.

2. Picon RV, Fuchs FD, Moreira LB, Riegel G, Fuchs SC. Trends in prevalence of hypertension in brazil: a systematic review with meta-analysis. PLoS One [Internet]. 2012 [cited 2017 Dec 10];7(10); e48255. Available from: https://www.ncbi.nlm.nih.gov/pmc/articles/PMC3485225/ pdf/pone.0048255.pdf

3. Pinho NA, Pierin AMG. Hypertension control in Brazilian publications. Arq Bras Cardiol [Internet]. 2013 [cited 2017 Dec 10];101(3):e65-e73. Available from: https://www.ncbi.nlm.nih.gov/pmc/articles/PMC4032316/pdf/abc-101-03-0e65.pdf

4. Mansur AP, Favarato D. Trends in mortality rate from cardiovascular disease in Brazil, 1980-2012. Arq Bras Cardiol [Internet]. 2016 [cited 2017 Dec 10];107(1):20-25. Available from: https://www.ncbi.nlm.nih.gov/pmc/articles/PMC4976952/pdf/abc-107-01-0020.pdf

5. Kung $\mathrm{H}$, Xu J. Hypertension-related mortality in the United States, 2000-2013. Centers for Disease Control and Prevention. NCHS Data Brief [Internet]. 2015 [cited 2017 Dec 11]; (193):1-8. Available from: https://www.cdc.gov/nchs/data/databriefs/db193.pdf

6. Sabageh B, Pelemo OE, Komolafe AO, Sabageh AO, Odesanmi WO. An autopsy review of sudden unexpected natural deaths in a suburban Nigerian population. Popul Health Metr. 2014;12:1-14. DOI: https://doi.org/10.1186/s12963-014-0026-9

7. Ferretti REL, Damin AE, Brucki SMD, Morillo LS, Perroco TR, Campora F, et al. Post-Mortem diagnosis of dementia by informant interview. Dement Neuropsychol [Internet]. 2010 [cited 2017 Dec 11];4(2):138-44. Available from: http://www.scielo.br/pdf/dn/v4n2/1980-5764-dn-4-02-00138.pdf

8. Ferretti REL, Jacob-Filho W, Suemoto CK, Farfel JM, Leite REP, Grinberg LP. Factors associated with morphometric brain changes in cognitively normal aging. Dement Neuropsychol [Internet]. 2015 [cited 2017 Dec 11];9(2):103-109. Available from: http://www.scielo. br/pdf/dn/v9n2/1980-5764-dn-09-02-00103.pdf

9. Brasileira de Empresas de Pesquisa. Critério de Classificação Econômica Brasil; 2014 [Internet]. São Paulo: ABEP; 2014 [citado 2017 dez. 16 ]. Disponível em: http://www.abep.org/criterio-brasil

10. American Psychiatric Association. Diagnostic and statistical manual of mental disorders: DSM-IV. 4th ed. Washington: APA;1994.

11. Andrade A, Pinto SC, Oliveira RS, organizadores. Animais de laboratório: criação e experimentação. Rio de Janeiro: Fiocruz; 2006.

12. Brasil. Ministério da Saúde; Conselho Nacional de Saúde. Resolução n. , de 12 de dezembro de 2012. Aprova as diretrizes e normas regulamentadoras de pesquisas envolvendo seres humanos [Internet]. Brasília; 2012 [citado 2017 dez. 18]. Disponível em: http://conselho. saude.gov.br/resolucoes/2012/Reso466.pdf

13. Chor D, Ribeiro ALP, Carvalho MS, Duncan BB, Lotufo PA, Nobre AA, et al. Prevalence, awareness, treatment and influence of socioeconomic variables on control of high blood pressure: results of the ELSA-Brasil Study. PLoS One [Internet]. 2015 [cited 2017 Dec 18]; 10(6):e0127382. Available from: https://www.ncbi.nlm.nih.gov/pmc/articles/PMC4478044/

14. Joffres M, Falaschett E, Gillespie C, Robitaille C, Loustalot F, Poulter N, et al. Hypertension prevalence, awareness, treatment and control in national surveys from England, the USA and Canada, and correlation with stroke and ischaemic heart disease mortality: a cross-sectional study. BMJ Open [Internet]. 2013 [cited 2017 Dec 19];3(8):e003423. Available from: https://www.ncbi.nlm.nih.gov/pmc/articles/PMC3758966/

15. Andrade SSA, Stopa SR, Brito AS, Chueri PS, Szwarcwald CL, Malta DC. Prevalência de hipertensão arterial autorreferida na população brasileira: análise da Pesquisa Nacional de Saúde, 2013. Epidemiol Serv Saúde [Internet]. 2015 [citado 2018 jan. 08];24(2):297-304. Disponível em: http://www.scielo.br/pdf/ress/v24n2/2237-9622-ress-24-02-00297.pdf 
16. Cesarino CB, Cipullo JP, Martin JFV, Ciorlia LA, Godoy MRP, Cordeiro JA, et al. Prevalence and Sociodemographic Factors in a Hypertensive Population in São José do Rio Preto, São Paulo, Brazil. Arq Bras Cardiol [Internet] 2008 [cited 2018 Jan 08];91(1):31-35. Available from: http://www.scielo.br/pdf/abc/v91n1/en_a05v91n1.pdf

17. Ojeda NB, Grigore D, Robertson EB, Alexander BT. Estrogen protects against increased blood pressure in postpubertal female growth restricted offsprin. Hypertension [Internet]. 2007 [cited 2018 Jan 08];50(4):679-85. Available from: https://www.ncbi.nlm.nih.gov/pmc/ articles/PMC2850594/

18. Silva SSBE, Oliveira SFSB, Pierin AMG. The control of hypertension in men and women: a comparative analysis. Rev Esc Enferm USP [Internet]. 2016 [cited 2018 Jan 12];50(1):50-8. Available from: http://www.scielo.br/pdf/reeusp/v50n1/0080-6234-reeusp-50-01-0050.pdf

19. Olack B, Wabwire-Mangen F, Smeeth L, Montgomery JM, Kiwanuk N, Breiman RF. Risk factors of hypertension among adults aged 35-64 years living in an urban slum Nairobi, Kenya. BMC Public Health [Internet]. 2015 [cited 2018 Jan 12];15:1251. Available from: https://www.ncbi.nlm.nih.gov/pmc/articles/PMC4683777/

20. Mion Júnior D, Pierin AMG, Bambirra AP, Assunção JA, Monteiro JM, Chinen RY et al. Hypertension in employees of a University General Hospital. Rev Hosp Clin Fac Med S Paulo [Internet]. 2004 [cited 2018 Jan 15];59(6):329-36. Available from: http://www.scielo.br/pdf/rhc/ v59n6/a04v59n6.pdf

21. Landsberg L, Aronne LJ, Beilin LJ, Burke V, Igel LI, Lloyd-Jones D, et al. Obesity-related hypertension: pathogenesis, cardiovascular risk, and treatment: a position paper of The Obesity Society and the American Society of Hypertension. J Clin Hypertens. 2013;15(1):14-33. DOI: $10.1111 /$ jch.12049

22. Deng W, Wang J, Liu M, Wang D, Zhao Y, Liu Y, et al. Body mass index compared with abdominal obesity indicators in relation to prehypertension and hypertension in adults: The CHPSNE Study. Am J Hypertens. 2013;26(1). DOI: 10.1093/ajh/hps001.

23. Monteiro CA, Conde WL, Popkin BM. Income-specific trends in obesity in Brazil: 1975-2003. Am J Public Health [Internet]. 2007 [cited 2018 Jan 20];97:1808-12. Available from: https://www.ncbi.nlm.nih.gov/pmc/articles/PMC1994168/

24. Zomer E, Leach R, Trimmer C, Lobstein T, Morris S, James WP, et al. Effectiveness and cost-effectiveness of interventions that cause weight loss and reduce the risk of cardiovascular disease. Diabetes Obes Metab. 2016;19(1) :118-24. DOI: 10.1111/dom.12792

25. Zhang H, Pan L, Ma Z, Chen Z, Huang Z, Sun Q, et al. Long-term effect of exercise on improving fatty liver and cardiovascular risk factors in obese adults: a 1-year follow-up study. Diabetes Obes Metab. 2016;19(2):284-9. DOI: 10.1111/dom.12809

26. Schmidt MI, Hoffmann JF, Diniz MFS, Lotufo PA, Griep RH, Bensenor IM. High prevalence of diabetes and intermediate hyperglycemia: The Brazilian Longitudinal Study of Adult Health (ELSA-Brasil). Diabetol Metab Syndr. 2014; 6:123. DOI: https://doi.org/10.1186/1758-5996-6-123

27. Noh J, Kim HC, Shin A, Yeom H, Jan S, Lee JH, et al. Prevalence of comorbidity among people with hypertension: The Korea National Health and Nutrition Examination Survey 2007-2013. Korean Circ J [Internet]. 2016 [cited 2018 Jan 25];46(5):672-680. Available from: https://www.ncbi.nlm.nih.gov/pmc/articles/PMC5054180/

28. Ettehad D, Emdin CA, Kiran A, Anderson SG, Callender T, Emberson J, et al. Blood pressure lowering for prevention of cardiovascular disease and death: a systematic review and meta-analysis. Lancet. 2016;387(10022):957-67. DOI: https://doi.org/10.1016/S0140-6736(15)01225-8.

29. Santos IS, Bittencourt MS, Rocco PT, Pereira AC, Barreto SM, Brunoni AR, et al. Relation of anxiety and depressive symptoms to coronary artery calcium (from the ELSA-Brasil Baseline Data). Am J Cardiol. 2016;118(2):183-7. DOI: 10.1016/j.amjcard.2016.04.048.

30. Gawryszewski VP, de Souza MFM. Mortality due to cardiovascular diseases in the Americas by region, 2000-2009. Sao Paulo Med J [Internet]. 2014 [cited 2018 Jan 25]; 132(2):105-10. Available from: http://www.scielo.br/pdf/spmj/v132n2/1516-3180-spmj-132-02-00105.pdf 